\section{Birlesik Dúnya Arastrma Cypriot Journal of Educational \\ Sciences}

Volume 15, Issue 2, (2020) 349-357

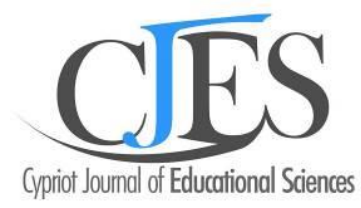

www.cjes.eu

\title{
Development of teacher-parent communication competence scale (TPCCS)
}

Zehra Ozcinar *, Ataturk teacher Training Academy, Department of Primary School Teaching, Lefkosa, North Cyprus, Turkey https://orcid.org/0000-0002-1974-2958

\section{Suggested Citation:}

Ozcinar, Z. (2020). Development of teacher-parent communication competence scale (TPCCS). Cypriot Journal of Educational Science. 15(2), 349-357. https://doi.org/10.18844/cjes.v15i2.4806

Received November 5, 2019; revised February 1, 2020; accepted April 1, 2020.

${ }^{\circ} 2020$ United World Center of Research Innovation and Publication. All rights reserved.

\begin{abstract}
The purpose of this study was to develop teacher-parent communication competence scale in order to measure the communication competences utilized by teachers while communicating with the parents of their students. In the development phase of the scale, an item pool was generated and draft form was designed which were later subjected to expert opinion for content and face validity. The finalized scale was administered to 196 teachers teaching fourth and fifth grade students, and explanatory factor analysis was performed. As a result of these procedures, 4 factors including 33 items in total were generated in the "teacher-parent communication competence scale". Apart from these, the reliability coefficients (Cronbach's $\alpha$ ) of all scales and their sub-dimensions, factor-based differentiation operations, matter-remaining and matter-total correlations were calculated. After all these validity and reliability processes, it was concluded that the scale is valid in determining teacher - parent communication competences.
\end{abstract}

Keywords: Primary School, Teacher, Parent, Communication Competence, Scale Development

* ADDRESS FOR CORRESPONDENCE: Zehra Ozcinar , Ataturk teacher Training Academy, Department of Primary School Teaching, Lefkosa, North Cyprus, Turkey

E-mail address: zehra.ozcinar@aoa.edu.tr 
Ozcinar, Z. (2020). Development of teacher-parent communication competence scale (TPCCS). Cypriot Journal of Educational Science. 15(2), 349-357 https://doi.org/10.18844/cjes.v15i2.4806

\section{Introduction}

Human beings are equipped with not only innate patterns of instinctive behaviour but also lateracquired patterns of behaviour. The most important characteristic that distinguishes human beings from other living things is that they acquire new behaviours through learning, and can communicate these with the generations that come after them. Within this context, education is regarded as the most effective way to convey this legacy to the next generations. As the result of the needs educational processes lead, many researches have been conducted to facilitate learning. As Bloom's taxonomy suggests learning becomes permanent at the levels of analysis and synthesis, and permanency of learning has been a frequently researched area (El-Adl \& Alkharusi, 2020; Zorluoglu, Kizilaslan \& Donmez Yapucuoglu, 2020).

The main aim of the education for professional purposes is to provide students with career-specific knowledge and skills, and prepare them for the situations they would face and be involved in their professional lives. Because of today's fast-paced changes, it is desirable that students are equipped with the interdisciplinary knowledge they need to familiarize with the conditions they are likely to encounter, and above all, to handle them (Damy, 2020).

Many of the challenges associated with education may arise from time to time, even in chains. However, the question of how to handle these problems leads to some other questions. In such a case, systems approach, which suggests the examination of mutual relationships and interactions as well as individual problems, might be adopted (Köymen, 1991). Therefore, the design, implementation and evaluation phases of teaching-learning, that is to say, the elements which comprise the educational system, must be taken into consideration while dealing with the problems pertaining to educational technology.

The theoretical foundations of educational technology are based on the concepts of philosophy, communication, teaching, learning and systems, as well as principles derived from various disciplines, because of the fact that the effectiveness of teaching-learning processes depends largely on the conscious application of theoretical knowledge about human learning and teaching. Therefore, systems approach can serve as the theoretical basis of educational technology and a process to be implemented in the purposeful arrangement of the elements that constitute educational technology (Read, 2020; Tenekeci \& Uzunboylu, 2020; Demir, 2020; Ergin, 1995). In this context, as Schramm (1954, as cited in Ergin, 1995) noted, communication, mostly studied as an element of some other field of study, must be considered as an independent discipline, and as a tool in forming the behaviours necessary for the success of learning-teaching processes (Deryakulu, 1992)

Learning takes place through the communication and interaction of students with their environment. During learning, the student interacts with the teacher and the environment he or she organizes because learning is guided by the teacher and it aims to provide permanent and desired behavioural change in the students in accordance with the objectives previously determined in the educational programs, which is also called teaching (Kukey, Gunes \& Genc, 2019). In this process, provision, utilization and management of learning facilities and structuring the learning environment accordingly would improve the quality of teaching and learning (Kingsley, 2019).

Besides, effectiveness and success of the teaching-learning processes depends on the impact and success of the communication to be established in these processes (Alkan, 1995). In other words, learning means permanent monitored behavioural change which occurs in the individual as a result of communication processes (Ergin, 1995). This mutual relationship between teaching and learning processes has brought the concept of communication technology to the agenda for the sake of successful and active teaching-learning (Gunes, 2019). What is expected from this technology is the expansion of educational opportunities, the improvement of teaching-learning processes, the 
provision of educational opportunities to regions not served adequately, and the support for teaching staff and materials when they are insufficient (Usluata, 1990).

Among the human resources of educational technology are educators who develop theories, teaching methods and educational tools for educational technology, as well as teachers who interact with students, and though indirectly, parents of students who are thought to contribute to educational processes in or out of school.

Ways to communicate can be learnt. Sometimes, rather than effective and healthy communication ways, useless ones that sometimes do not work are also learned (Wyckoff \& Unell, 1991). Effective healthy communication is made possible by people understanding each other correctly, communicating it to each other, treating each other with respect, feeling that they understand and are understood. Since the first examples of communication are experienced in the family, communication between family members is an important element in learning the ways of communication because "people who are able to establish healthy and fulfilling relationships with family and friends are more satisfied with themselves and with life" (Cüceloğlu, 1994). In reality, interpersonal relationships -no matter among whom they are- lead to happiness when they are effective, and their principles are the same. Only what is spoken differs. Concerning the child-parent relationship, children and their parents communicate while eating, sleeping and playing, and the issues related to school are basically discussed in the case of presence of school-aged children at home; however, when the relationship between mother and father is considered, it is seen that private relations, monetary issues, current events are the most discussed topics (Aytaç, Demirbas-Celik, \& Kiracioglu, 2019; Korkut, 2002; Wyckoff \& Unell, 1991; Yavuzer, 1996).

In the eyes of parents, teachers are their children's other parents. Similarly, parents are students' other teachers in the eyes of teachers. If the teacher-student relationship is broken, the parent suffers, and if the parent-child relationship is broken, teacher suffers (Gordon, 1993). Based on that, the relationship between family and teacher plays an important role in forming the desired behavior to be performed by the student. When this correspondent relationship is examined closely, it is clear that parents strive for shaping their children's behaviour at home within the family while the teachers do the same in the school environment.

Studies on the role of the parents in this process and the communication between teacher and student in the learning-teaching processes have revealed that there has been a change in the traditional relationship between the teacher and student, and the role of parents. Arnold and Birne (1995), for example, introduced a new program through the concept of Family University and implied the need to educate parents for the success of the students. Concerned with this program, Mccartney (2000) noted that researchers focusing on the school context developed successful strategies to combine home with school, and emphasized that the applications designed to improve school-home relations are to understand and recognize students in a family and cultural context. Correspondingly, the statement in the National Educational Goals Panel (1996) saying that "each school should actively support parents to make joint decisions about their children's academic work in a common way in relation to the shared decisions required at home and at school" demonstrates the importance of parental involvement in student education.

If it is accepted that the family is responsible for the development and education of the child in all periods and has an important role in this regard, it can be said that this role is more intense and widespread in traditional society than in industrial societies because traditional family prepares the child for life by teaching the values and norms of society on the one hand, and certain knowledge and skills required by the society on the other hand. However, rapid social changes that occur due to the influence of science and technology have led to significant changes in the roles and functions of members in the family system. Moreover, having been one of these social institutions, the school is 
increasingly being responsible for the education of the child, and as one of the stakeholders the teacher also has significant duties.

There has been a lot of research in the literature on improving the family-school rela-tionship and its natural reflections on student behaviour, most of which were conducted at preschool or secondary education levels. Emphasizing the importance of enabling parents to assist their children in their studies at home and to inform them about their studies at school it is concluded in many studies that there was a positive relationship between teacher-parent communication and their children's school success (Hill \& Tyson, 2009).

Despite that, as Parker (1997) marked, parent involvement in studies has been low and limited to small samples. Also, current definitions made for parental involvement are inade-quate and fragmented. Up till today, insufficient information has been obtained with regard to multidimensional family involvement when compared with the proportion of children in pre-school education and primary education. Erdoğan and Demirkasimoğlu (2010) found that most families are reluctant and passive to be involved in the educational processes, and their involvement is mostly limited to activities like family visits to school and exchanging infor-mation, taking teachers ' advice, attending meetings when invited. Among the leading obsta-cles to the involvement of families in the process are negative attitudes of families and educa-tors. They argued in their study that there was not enough work done to eliminate the factors that prevent familial involvement in schools or to increase participation.

Students constitute $17 \%$ of the world's population (UNESCO, 2014), leading educa-tion to be a system that works on the same purpose in a one-piece sense in the world even if there are differences from country to country and culture to culture in terms of the policies and implementations. Events such as war, natural disasters and epidemics in the history of the world have caused some stakeholders of the system to be deprived of education from time to time. In general, however, there has never been such an event that affects education in the whole world as deeply as the current epidemic. As of today, $82 \%$ of students, worldwide, are out of school (UNESCO, 2020). That number was around $60 \%$ a short time ago. In other words, access to the controlled, disciplined model of formal education paved way by the in-dustrial revolution has dropped to $18 \%$ in the world. (Toker, 2020)

As a result of the coronavirus (COVID-19) outbreak, which started in Wuhan, China, and took effect all over the world from the first months of 2020, a number of measures has been taken in education and face-to-face training has been decommissioned and education has been moved to digital media. This has brought about many changes which have affected stu-dents as well as their parents. Parents are concerned about the potential risks associated with these disruptions in education and about the future for their children. Furthermore, the fact that their children are at home during this period and the need for parents to take the control of time has made them quite involved in the learning process of the children.

Within this context, education has now had to turn into a kind of parent-led phenome-non, and school-family cooperation has become more important than ever. Teachers are also required to be actively involved in the process using the communication technologies of the age. If the education has to be carried out under the guidance of the teacher and under the direction of the parent, it has also been a necessity to raise the awareness of the parents by the hand of the teachers. As a result, communication competences become more important as teachers' communication with parents about students' knowledge, skills and attitudes have become more prominent than ever, which arose the need to conduct this study and develop a teacher-parent communication competence scale. 


\section{Method}

\subsection{Subjects of the Study}

The target population of this study was all 4th and 5th grade students, their parents and teachers teaching at 32 primary schools located in Nicosia and Guzelyurt, and affiliated with Ministry of National Education of Turkish Republic of Northern Cyprus. Therefore, the subjects of this study consisted of three homogeneous subgroups, who are teachers, students and their parents. Among these subgroups, it was aimed to reach only all classroom teachers teaching 4th and 5th grade students. Out of a total of 32 primary schools, four schools were excluded from the study due to the fact that some students in these schools were not planning to prepare for "College Entrance Exams", some groups included less than five students, and some groups were tutored through combined classroom method. Based on this exclusion, 196 teachers teaching 4th and 5th grade students at 28 primary schools in Nicosia and Guzelyurt region were included in the study.

\subsection{Instrumentation}

In order to determine the communication competence level of teachers with the parents and develop a scale to measure communication competences used by teachers while communicating with parents several steps were taken. In the first place, a list including all classroom teachers was printed and contacted. Among them, a group of convenient teachers were selected and they were asked to write composition in order to provide data for the item pool. Besides, the notes kept by them were examined. Additionally, examples of scale development by Fantuzzo, Tighe and Childs (2000), Epstein (1995) and Daniel (1983) were also considered while generating the initial pool of items.

Based on these, the draft form was designed using the pool of items to determine communication competences. To ensure the content validity, each item in the scale was examined by the experts $(n=15)$ to assess the degree of responsiveness to the purpose. The group of experts, consisting of educational scientists, evaluated each item in the data collection tool individually or in groups. Necessary revisions were made on the draft form in line with expert opinions. In this way, content validity and format of the scales were established. The finalized version of the scale was administered to 196 teachers selected from the population. Permission received to pilot the scale with this group is given in Annex 1.

In the finalized version, a quintuple rating scale was used to measure communication competences based on teachers' perceptions. Answers to each item, ranging from "always", "most of the time ", "sometimes ", "rarely" and to "never", were collected using five-point Likert type scale. Responses to positive statements on the scales ranged from 5 to 1, from "always" to "never". With regard to the negative statements, scoring was done in reverse. Accordingly, high scores from the scales indicated high communication competences.

\section{Results}

This scale was developed to determine the communication competences of primary school teachers utilized by them for communication with parents. The finalized form of this scale was administered to 196 primary school teachers. Exploratory factor analysis was carried out to examine the construct validity of the scale. When the initial results of the factor analysis were examined, it was observed that 2 out of the 35 items in the piloted form of the scale revealed a factor loading value below .30 or had a high loading value in more than one factor. Such items were removed from the scale and factor analysis for the remaining 33 items were run again. 
The analysis indicated that the first factor loading values of the items varied between .38 and .72 , and the variance explained by the single factor was $33.8 \%$. Furthermore, as a result of further investigations, it was thought that the scale could be four-factor. The "eigenvalue greater than 1 criterion" was used to determine the common factors to retain. The eigenvalues used to find the variance explained by the factors in the study were 11.15 for the first factor, 2.70 for the second factor, 1.99 for the third factor, and 1.64 for the fourth factor, while the eigenvalues for the fifth and ninth factors ranged from 1.32 to 1.01 .

Accordingly, the first factor named "use of school environment" consisted of 5 items, and loading values of post-rotation substances varied between .38 and .74 , explaining $16.19 \%$ of the total variance. The second factor, which is named as "activities for informing parents", consisted of 10 items, and the loading values of post-rotation items varied between .29 and .62, accounting for $13,19 \%$ of the total variance. The third factor, "teacher- parent status", consisted of 12 items, item loading values of which ranged between .32 and .80 after rotation, and explained $13,02 \%$ of the total variance. The fourth factor, "parents' access to the teacher", included 6 items and their loading values after rotation ranged between.42 and .69, accounting for $10.57 \%$ of the total variance. The total amount of variance explained by these four factors was found to be $52.97 \%$, indicating that this scale can be used in single and four factors.

As a result of the analyses on the distinguishing properties of the items on the scale, it was observed that the item-total correlations of 33 items varied between .35 and .68. It was calculated that the item-total correlations ranged from .48 to .67 for the items within the first factor. The same coefficients were calculated for the second factor and found to be ranging from .44 to .67. The correlation coefficients proved to be between .39 and .65 for the third factor, and between .47 and .59 for the fourth factor.

Cronbach alpha and $95 \%$ confidence interval for reliability coefficients were also calcu-lated in order to determine the internal consistency of the scores. The Cronbach's alpha coeffi-cients over .70 were accepted adequate for an instrument to be used (Özgüven, 2004). The al-pha coefficients [and $95 \%$ confidence intervals] for the whole scale was found to be .94 , and .77 for the first factor, .84 for the second factor, .87 for the third factor, and .78 for the fourth factor, respectively.

The results of factor loadings and item analysis of TPCCS are presented in Table 1 given below:

Table 1. Teachers-Parent Communication Competence Scale (TPCCS) Factor Loadings

\begin{tabular}{|c|c|c|c|c|c|}
\hline $\begin{array}{l}\text { Item } \\
\text { No }\end{array}$ & Items & $\begin{array}{c}\text { Factor Loadings } \\
\text { Before Rotation }\end{array}$ & $\begin{array}{c}\text { Factor Loadings } \\
\text { After Rotation }\end{array}$ & $\begin{array}{l}\text { Item } \\
\text { Total } \\
\quad R\end{array}$ & $\begin{array}{c}\text { Subtest } \\
\text { Item } \\
R\end{array}$ \\
\hline & $\begin{array}{l}\text { Factor 1: Using School Environment } \\
\text { to Benefit from School }\end{array}$ & & & & \\
\hline 10. & $\begin{array}{l}\text { I make sure parents make use of the } \\
\text { school's playgrounds and sports } \\
\text { facilities. }\end{array}$ & .641 & .740 & .598 & .499 \\
\hline 15. & $\begin{array}{l}\text { I advise parents for summer activities } \\
\text { and next year/semester. }\end{array}$ & 672 & .382 & 629 & .480 \\
\hline 12. & $\begin{array}{l}\text { I meet parents in a regular, aesthetic } \\
\text { environment. }\end{array}$ & .719 & .435 & 675 & 671 \\
\hline 3. & $\begin{array}{l}\text { I make sure parents contribute to the } \\
\text { school's social activities. }\end{array}$ & 601 & .441 & .561 & .559 \\
\hline 6. & $\begin{array}{l}\text { I mention about appropriate facilities } \\
\text { requiring special talent (music, } \\
\text { sports...) to be prepared at school and } \\
\text { in similar environment for students. } \\
\text { Factor } 2 \text {. Activities to inform parents }\end{array}$ & .512 & .597 & .463 & .539 \\
\hline 8. & I address to parents' lack of & .695 & .617 & .658 & 674 \\
\hline
\end{tabular}




\begin{tabular}{|c|c|c|c|c|c|}
\hline & $\begin{array}{l}\text { knowledge about education and } \\
\text { school. }\end{array}$ & & & & \\
\hline 23. & I'll get the parents to visit the school. & .553 & .597 & .516 & .553 \\
\hline 1. & $\begin{array}{l}\text { I inform parents about effective } \\
\text { course work techniques. }\end{array}$ & .636 & .594 & .590 & .620 \\
\hline 31. & $\begin{array}{l}\text { I make sure I meet the parents after } \\
\text { school. I'll tell the parents what to } \\
\text { do/what not to do. }\end{array}$ & .455 & .584 & .420 & .420 \\
\hline 27. & $\begin{array}{l}\text { I make sure I meet the parents after } \\
\text { school. I'll tell the parents what to } \\
\text { do/what not to do. }\end{array}$ & .414 & .574 & .384 & .442 \\
\hline 19. & $\begin{array}{l}\text { I participate with parents in the event } \\
\text { of conferences for students to learn. }\end{array}$ & .576 & .294 & .546 & .438 \\
\hline 4. & $\begin{array}{l}\text { I help students plan for their leisure } \\
\text { time. }\end{array}$ & .646 & .520 & .602 & 618 \\
\hline 24. & $\begin{array}{l}\text { I inform parents about the aims and } \\
\text { activities of the school. }\end{array}$ & .575 & .485 & .532 & .438 \\
\hline 9. & $\begin{array}{l}\text { I help in areas where parents want to } \\
\text { improve themselves. }\end{array}$ & .543 & .286 & .492 & .509 \\
\hline 5. & $\begin{array}{l}\text { I make a joint plan with the parent for } \\
\text { the development of the student } \\
\text { Factor } 3 \text {. The state of the teacher } \\
\text { dealing with the parent }\end{array}$ & .672 & .348 & .348 & .606 \\
\hline 25. & I know the address of parent & .525 & .804 & .509 & .597 \\
\hline 26. & $\begin{array}{l}\text { I know the phone number of the } \\
\text { parent }\end{array}$ & .549 & .775 & .521 & .590 \\
\hline 17. & $\begin{array}{l}\text { I inform parents about my free time } \\
\text { in school }\end{array}$ & .642 & .629 & 609 & .648 \\
\hline 11. & $\begin{array}{l}\text { I make my planning before seeing the } \\
\text { parent }\end{array}$ & .617 & .594 & .582 & .607 \\
\hline 28. & $\begin{array}{l}\text { I send notes to parents about the } \\
\text { assignments in school }\end{array}$ & .609 & .438 & .580 & .524 \\
\hline 21. & $\begin{array}{l}\text { I inform parent about everything } \\
\text { related to student }\end{array}$ & .445 & .422 & .418 & .397 \\
\hline 29. & $\begin{array}{l}\text { I send news letters to the parent to } \\
\text { receive feedback. }\end{array}$ & .507 & .416 & .472 & .486 \\
\hline 16. & $\begin{array}{l}\text { I visit parents ' houses at certain } \\
\text { periods. }\end{array}$ & .702 & .341 & .662 & 639 \\
\hline 7. & $\begin{array}{l}\text { I make home visits to get to know } \\
\text { parents better }\end{array}$ & .665 & .382 & .629 & .608 \\
\hline 30. & $\begin{array}{l}\text { I have informal meetings with } \\
\text { parents. }\end{array}$ & .665 & .366 & .626 & .592 \\
\hline 20. & $\begin{array}{l}\text { I'll send home a progress list for the } \\
\text { student's progress. }\end{array}$ & .523 & .318 & .480 & .523 \\
\hline 18. & $\begin{array}{l}\text { I call the parent when the student } \\
\text { doesn't attend to school } \\
\text { Factor 4: The state of parent to reach } \\
\text { the teacher }\end{array}$ & .611 & .358 & .569 & .539 \\
\hline 22. & $\begin{array}{l}\text { Parents can call me freely to talk } \\
\text { about the student }\end{array}$ & .407 & .688 & .384 & .545 \\
\hline 33. & I make phone calls with parent & .577 & 649 & .546 & .590 \\
\hline 2. & $\begin{array}{l}\text { I can reach parent that is open to } \\
\text { collaboration }\end{array}$ & .417 & .584 & .388 & .469 \\
\hline 32. & I only make phone calls with parent & .566 & .577 & .538 & .597 \\
\hline 13. & I give my phone number to parent & .375 & .555 & .351 & .544 \\
\hline 14. & $\begin{array}{l}\text { If needed I can meet parent outside } \\
\text { the school hours in any time. }\end{array}$ & .658 & .582 & .415 & .491 \\
\hline
\end{tabular}




\section{Discussion and Conclusion}

In this study, a 35-item teacher-parent communication competence measurement tool was developed to measure the communication competences utilized by the teachers to com-municate with their students' parents, and was first subjected to the expert review for estab-lishing content validity. This measurement tool was administered to the teachers teaching 4th and 5th grade students, and then, explanatory factor analysis was conducted to examine the structure validity of the scales, generating a 33-item teacher parent communication compe-tence scale. Apart from these, the reliability coefficients (Cronbach's $\alpha$ ) of all scales and their sub-dimensions, factor-based differentiation operations, matter-remaining and matter-total correlations were calculated.

As the result of these processes, TPCCS including 33 items within 4 factors was found valid and reliable to examine the competences used by teachers to communicate with the parents of their students. This result is consistent with the results of some other scale develop-ment studies. For example, Özbaş (2013), Kaplan (2018) and Kısaç (2017) produced similar results with this study and concluded that relationship between students, teachers and parents are necessary for effective learning.

As for implications, this study may also be indicator of the need to develop a scale for measuring students' communication competences with their parents and compare these compe-tences with the teachers' in terms of major variables. Moreover, this study was limited to the teachers serving at primary education level. This study can be replicated by administering this scale to the teachers teaching at other education levels like 6th, 7th and 8th grades. Additionally, as the findings of this study were based on the opinions of the teachers further studies can include parents' views about teachers' communication competences and this scale can be im-proved. Finally, the existing scale included items related to face-to-face communication be-tween parents and teachers. Considering the developing technology, it is recommended that new scales be developed by including items related to different methods and techniques of communication and communication applications.

\section{Acknowledgement}

This article was extracted and updated from the author's thesis titled "Communication competences of teachers-parents-students and the relation between these competences and the students' success", which was completed at Ankara University, Institute of Educational Sciences at Educational Sciences Department in Ankara in 2003.

\section{References}

Arnold, L. B., \& Birne, A. M. (1995). Parent university: A new program in Union City, New Jersey, ensures the success of students by educating their parents. Science Teacher, 62(8), 29-31.

Aytaç, P., Demirbas-Celik, N., \& Kiracioglu, D. (2019). Effectiveness of family involvement activities in pre-school education. Global Journal of Guidance and Counseling in Schools: Current Perspectives, 9(3), $131-137$. https://doi.org/10.18844/gjgc.v9i3.4489

Balcı A. (2007). Sosyal bilimlerde araştırma yöntem teknik ve ilkeler [Research methods, techniques and principles in social sciences]. Ankara: PegemA Yayıncılık

Cüceloğlu, D. (1994). Yeniden insan insana (Human to human again). İstanbul. Remzi Kitabevi.

Damy, A. (2020). Interdisciplinary block of learning challenges. Contemporary Educational Researches Journal, 10(1), 21-27. https://doi.org/10.18844/cerj.v10i1.4611

Daniel, A. (1983). Development of a perceived communication effectiveness scale. Paper presented at the Annual Meeting of the International Communication Association, Dallas, Texas. https://eric.ed.gov/?id=ED233405

Demir, B. (2020). Evaluation of social studies teaching textbooks. International Journal of Learning and Teaching, 12(1), 1729. https://doi.org/10.18844/ijlt.v12i1.4563 
Ozcinar, Z. (2020). Development of teacher-parent communication competence scale (TPCCS). Cypriot Journal of Educational Science. 15(2), 349-357 https://doi.org/10.18844/cjes.v15i2.4806

Deryakulu, D. (1992). Eğitim iletişimi kavramı [The concept of education communication]. Ankara. Eğitim Bilimleri Dergisi. 252.

El-Adl, A., \& Alkharusi, H. (2020). Relationships between self-regulated learning strategies, learning motivation and mathematics achievement. Cypriot Journal of Educational Sciences, 15(1), $104-111$. https://doi.org/10.18844/cjes.v15i1.4461

Epstein, J. L. (1995). School/ family/community partnerships. Phi Delta Kappa. 76, 701-712.

Erdoğan, Ç., \& Demirkasımoğlu, N. (2010). Ailelerin eğitim sürecine katılımına ilişkin öğretmen ve yönetici görüşleri [Teachers' and administrators' perceptions about familial involvement in education]. Kuram ve Uygulamada Eğitim Yönetimi, 16(3), 399-431.

Ergin, A. (1995). Öğretim teknolojisi iletişim [Instructional technology communication]. Pegem Yayınları, Ankara.

Fantuzzo, J., Tighe, E., \& Childs, S. (2000). Family Involvement Questionnaire: A multivariate assessment of family participation in early childhood education. Journal of Educational Psychology, 92(2), 367-376. https://doi.org/10.1037/0022-0663.92.2.367

Gordon, T. (1993). Etkili öğretmenlik eğitimi [Effective teacher education]. Birinci Basım. Ya-pa yayınları, İstanbul.

Güneş, S. (2019). What are the perceptions of the students about asynchronous distance learning and blended learning? World Journal on Educational Technology: Current Issues, 11(4), $230-237$. https://doi.org/10.18844/wjet.v11i4.4274

Hill, N. E., \& Tyson, D. F. (2009). Parental involvement in middle school: a meta-analytic assessment of the strategies that promote achievement. Developmental Psychology, 45(3), 740-63.

Kaplan, G. (2018). Ortaokul öğrencilerine verilen matematik ödevleri hakkinda öğrenci, öğretmen ve veli görüşleri [Students, teachers and parents ' perceptions about math homework assigned to secondary school students]. Unpublished master's thesis, Marmara Üniversitesi Eğitim Bilimleri Enstitüsü, İstanbul.

Kingsley, O. (2019). Management of learning facilities. New Trends and Issues Proceedings on Humanities and Social Sciences, 6 (7), 82-87. https://doi.org/10.18844/prosoc.v6i7.4516

Kısaç, i. (2017). Öğretmen-öğrenci iletişimi [Teacher-student communication]. Pegem Atıf indeksi, 114-132.

Korkut, F. (2002). Aile içi iletişim [Communication within family]. Eskisehir. Anadolu University Press, No. 1367.

Köymen, Ü. (1991). Nitelikli öğretmen yetiştirme modeli [A model for qualified teacher education]. Eğitimde Nitelik Geliştirme: 1. Eğitim Sempozyumu, ìstanbul.

Kukey, E., Gunes, H., \& Genç, Z. (2019). Experiences of classroom teachers on the use of hands-on material and educational software in math education. World Journal on Educational Technology: Current Issues, 11(1), 74-86. https://doi.org/10.18844/wjet.v11i1.4010

McCartney, S. (2000). Home-school connections: A review of literature. The Journal of Educational Research. 93(3), 145-153.

Özbaş, M. (2013). Perceptions of parents about the duties of primary school administrators related to the attendance education of primary school first grade students' families to school life. Education and Science, 170, 61-78.

Özgüven, i. E. (2004). Psikolojik testler [Psychological tests]. Ankara: PDREM Yayınları.

Read, T. (2020). Towards a new model for inclusive education based on virtual social inclusion and mobile openness. World Journal on Educational Technology: Current Issues, 12 (1), 14-22. https://doi.org/10.18844/wjet.v12i1.4507

Tenekeci, F., \& Uzunboylu, H. (2020). Determining the relationship between the attitudes of private teaching institution teachers towards lifelong learning and their competence. International Journal of Learning and Teaching, 12 (1), 116. https://doi.org/10.18844/ijlt.v12i1.4559

Toker, T. (2020). Pandemi döneminde öğretmen rehberliğinde veli liderliğinde evde eğitim [Parent-led home-schooling under teacher guidance during the pandemic period]. March 27, 2020, Retrieved from; http://www.kamudanhaber.net/guncel/pandemi-doneminde-ogretmen-rehberliginde-veli-liderliginde-evde-egitimh431233.html

US Department of Education (1992). National Education Goals. Washington. DC.

Wyckoff, J., \& Unell, B. C. (1991). How to discipline your six to twelve year old without losing your mind. New York: Doubleday, 1991.

Yavuzer, H. (1996). Çocuk eğitimi el kitabı [Handbook of child education]. Remzi kitabevi, İstanbul.

Zorluoglu, S., Kizilaslan, A., \& Donmez Yapucuoglu, M. (2020). The analysis of 9th grade chemistry curriculum and textbook according to revised Bloom's taxonomy. Cypriot Journal of Educational Sciences, 15(1), 9-20. https://doi.org/10.18844/cjes.v15i1.3516 